Original Research Paper

\title{
An Assessment of GHGs Reduction Potential from Bio- Electricity Generation: Agricultural Waste-to-Energy Project in Thailand as a Case Study
}

\author{
${ }^{1}$ Kittipongvises Suthirat and ${ }^{2}$ Polprasert Chongrak \\ ${ }^{I}$ Environmental Research Institute, Chulalongkorn University (ERIC), Bangkok 10330, Thailand, Research Program of Toxic \\ Substance Management in the Mining Industry, Center of Excellence on Hazardous Substance Management (HSM), Bangkok \\ 10330, Thailand, Research Unit of Site Remediation on Metals Management from Industry and Mining (Site Rem), \\ Chulalongkorn University, Bangkok 10330, Thailand \\ ${ }^{2}$ Faculty of Engineering, Thammasat University, Thailand
}

\author{
Article history \\ Received: 25-05-2016 \\ Revised: 15-08-2016 \\ Accepted: 17-08-2016 \\ Corresponding Author: \\ Kittipongvises Suthirat \\ Environmental Research \\ Institute, Chulalongkorn \\ University (ERIC), Bangkok \\ 10330, Thailand \\ Email: suthirat.k@chula.ac.th
}

\begin{abstract}
Driven by concerns of energy security and global climate change, this study aimed to investigate the potential of greenhouse gases (GHGs) emissions reduction from bio-electricity project in Thailand. A cogeneration plant in which deploying biomass residues from sugar cane production was selected as a case study. By considering the ACM0006 method, namely "Consolidated methodology for electricity and heat generation from biomass", the findings indicated that the utilization of about 1,320,000 tonnes per year of excess bagasse and 100,000 tonnes per year of rice husk residues could potentially lower the amount of GHGs emissions approximately $102,441.09 \mathrm{tCO}_{2} \mathrm{e}$ per year. Under this scheme, over $90 \%$ of total baseline emissions came from electricity generation by biomass residues. Meanwhile, biomass combustion was considered to be the main source of GHGs emissions compared to other activities. Lack of systematic data collection and cohesion in calculation methods were the key barriers to development of bio-energy project in Thailand.
\end{abstract}

Keywords: Agricultural Wastes, Greenhouse Gases (GHGs) Reduction, Bio-Electricity, Thailand, Waste-to-Energy

\section{Introduction}

As a result of population growth and economic development, energy demand is expected to dramatically increase in the coming year. The enormous consumption of energy results in all countries being faced with tremendous pressure on energy access and security. In terms of environmental problems, the burning of fossil fuels has caused a great number of the serious problems, such as climate change and global warming caused by Greenhouse Gases (GHGs) emissions, the breakdown of the ozone layer, acid rains and the decrease in biodiversity (Serdar et al., 2013). Consequently, many countries have already taken initiatives and strong actions to improve efficiency of renewable energy, reduce their dependence on fossil fuels (IEA, 2009) and subsequently lower the amount of GHGs emitted to the atmosphere. For instance, the European Union has set its climate and energy targets of producing $20 \%$ of its total energy from renewable sources and also reducing
GHGs emissions at least $20 \%$ by 2020 (EPC, 2009). Recently, the UN Paris meeting or COP21 emphasized strong actions from all member countries to reduce GHGs emissions so as to limit global temperature increase to be less than well below $2^{\circ} \mathrm{C}$ by 2100 . Like many other countries, Thailand is also aware of the energy issue and is adopting long term targets for renewable energy in order to become a low carbon society (ONESDB, 2011). According to the Alternative Energy Development Plan (2012-2021), the country set an ambitious target of increasing the share of renewable energy consumption by $25 \%$ in 2021 (Sutabutr, 2012).

Meanwhile, according to the socio-geographical situation, Thailand is rich in natural resources and agricultural products that can make the country the best potential on alternative energy development, such as biogas, biomass, biofuels-ethanol and biodiesel, etc. and also create opportunity to strengthen energy security in the future. Agricultural waste is available in abundance in Thailand. Department of Alternative Energy Development and Efficiency of Thailand 
reported that the total amount of crop residues in Thailand in 2009 was approximately 59,539,905 tonnes. Rice husk, bagasse and cassava residues were the majority with $29,157,146,17,630,521$ and 78,721 tonnes, respectively. This is becoming a serious environmental problem as decomposed agricultural biomass releases methane $\left(\mathrm{CH}_{4}\right)$ and open burning by farmers in order to clear the land for planting generates $\mathrm{CO}_{2}$ and other air pollutants. However, the study on potential climate impacts and benefits of converting waste agricultural biomass into biofuel is somehow limited in Thailand. Consequently, this paper aims to assess the potential of GHGs reductions from bio-electricity cogeneration power plant in Thailand. An agricultural biomass waste-to-energy project (i.e., excess bagasse and rice husk) was selected as a case study.

\section{Literature Reviews}

\section{Total Net GHG Emission in Thailand}

As a part of the Second National Communication (ONEP, 2010), in 2000, the total net GHG emission in Thailand was 229.08 million tonnes carbon dioxide equivalent $\left(\mathrm{CO}_{2} \mathrm{e}\right)$. Energy sector was the largest contributor at about $70 \%$, followed by agricultural sector at $23 \%$. The remaining proportion was industry, forest and waste management, respectively. In terms of the agriculture sector, field burning of agricultural residues accounted for $1.9 \%$ of total emissions.

\section{Thailand Alternative Energy Development Plan (AEDP)}

Alternative Energy Development Plan (AEDP) B.E.2558-2579 (2015-2036) aims to achieve a $30 \%$ share of the country's total energy consumption in 2036. Solar and biomass energy generation have the most encouraging potentials to be developed in Thailand, as shown in Table 1.

\section{Thailand Bioenergy Potential}

Table 2 presents the potential and current use of bioenergy in Thailand in 2012. Renewable energy derived from biomass such as agricultural crops and wastes has the highest potential 9,231.82 kilotonnes of oil equivalent (ktoe) compared to biogas $(6,560.82 \mathrm{ktoe})$ and biofuel utilization (1,020.24 ktoe), respectively. Regarding biomass from agricultural-based industries, three major potential sources of bioenergy are sugar cane $(40 \%)$, rice $(18 \%)$ and oil palm sector (9\%) (NSTIPO and JGSEE, 2014).

\section{Feed-in Tariff (FiT) Mechanism in Thailand}

As a policy instrument to incentivize the utilization of renewable energy, Thailand was the first country to establish FiT program in the ASEAN. It was also called 'adder' because its adds premium or additional payment to all renewable energy generators on the top of normal prices. In this context, the adder rates mainly depend on energy technology and installed power (Tongsopit and Greacen, 2013; Pita et al., 2015; EPPO, 2010), as depicted in Table 3.

Table 1. Thailand's AEDP targets by 2036 (Theerarattananoon, 2015)

\begin{tabular}{lc}
\hline Energy Type & AEDP target (MW) \\
\hline Solar PV & 6,000 \\
Biomass & 5,570 \\
Hydro power & 3,282 \\
Wind power & 3,002 \\
Biogas from energy crop & 680 \\
Biogas & 600 \\
Municipal solid waste & 501 \\
Total & 19,635 \\
\hline
\end{tabular}

Table 2. Potential of bioenergy utilization in Thailand in 2012 (NSTIPO and JGSEE, 2014)

\begin{tabular}{lll}
\hline $\begin{array}{l}\text { Type of } \\
\text { bioenergy }\end{array}$ & $\begin{array}{l}\text { Quantity } \\
\text { for biomass } \\
\text { production }\end{array}$ & $\begin{array}{l}\text { Bioenergy } \\
\text { potential } \\
\text { (ktoe) }\end{array}$ \\
\hline $\begin{array}{l}\text { Agricultural residue } \\
\text { (Mt/yr) }\end{array}$ & 24.15 & $9,231,82$ \\
- Field based residues & $(17.23)$ & $(6,570.54)$ \\
- Process based residues & $(5.77)$ & $(2,196.70)$ \\
- Agro-based residues & $(1.15)$ & $(464.57)$ \\
Biogas utilization & $11,749.02$ & $6,560.82$ \\
(Mm $\left.{ }^{3} / y r\right)$ & & \\
Biofuel & $1,525.70$ & $1,020.24$ \\
(Mllyr) & $(883.3)$ & $(696.72)$ \\
- Biodiesel & $(642.4)$ & $(323.52)$ \\
- Ethanol & & $16,812.88$ \\
Total & & \\
\hline
\end{tabular}

Table 3. Thailand's adder rate (EPPO, 2010)

\begin{tabular}{|c|c|c|c|}
\hline \multirow[b]{2}{*}{$\begin{array}{l}\text { Type of } \\
\text { Renewable } \\
\text { energy }\end{array}$} & \multicolumn{3}{|c|}{ Unit: Thai Baht ${ }^{*}$ per kWh } \\
\hline & $\begin{array}{l}2007 \\
\text { Adder } \\
\text { rate }\end{array}$ & $\begin{array}{l}2009 \\
\text { Adder } \\
\text { rate }\end{array}$ & $\begin{array}{l}2010 \\
\text { Adder } \\
\text { rate }\end{array}$ \\
\hline \multicolumn{4}{|l|}{ Biomass } \\
\hline Capacity $\leq 1 \mathrm{MW}$ & 0.3 & 0.5 & 0.5 \\
\hline Capacity $>1 \mathrm{MW}$ & 0.3 & 0.3 & 0.3 \\
\hline \multicolumn{4}{|l|}{ Biogas } \\
\hline Capacity $\leq 1 \mathrm{MW}$ & 0.3 & 0.5 & 0.5 \\
\hline Capacity $>1 \mathrm{MW}$ & 0.3 & 0.3 & 0.3 \\
\hline \multicolumn{4}{|l|}{ Wind } \\
\hline Capacity $\leq 50 \mathrm{MW}$ & 3.5 & 4.5 & 4.5 \\
\hline Capacity $>50 \mathrm{MW}$ & 3.5 & 3.5 & 3.5 \\
\hline \multicolumn{4}{|l|}{ Small/Micro Hydro } \\
\hline $50 \mathrm{~kW}-200 \mathrm{MW}$ & 0.4 & 0.8 & 0.8 \\
\hline Capacity $\leq 50 \mathrm{~kW}$ & 0.8 & 1.5 & 1.5 \\
\hline Solar & 8.0 & 8.0 & 6.5 \\
\hline
\end{tabular}

Note: * Exchange rate: 1 US Dollars-35 Thai Baht (June 2016) 


\section{Materials and Methods}

\section{Case Study Selection}

This paper extends the analysis of a case study that examined bio-energy cogeneration project in Thailand. Company A, located in the central region of Thailand approximately 150 kilometers northwest of Bangkok, was selected as a key case. The bio-electricity project is biomass cogeneration plant deploying biomass agricultural residue from sugar cane production as primary fuel. Basically, the processing of sugarcane produces large amount of bagasse, which is used as fuel in a cogeneration to provide both stream and electricity for the sugar mill. Other agricultural residues such as rice husk are used to compensate for any shortfall in sugarcane throughput. The project activity also involves the capacity expansion of the existing biomass-fired cogeneration system located next to the sugar mill factory. Additional site visit and face-to-face interviews were also performed.

\section{Method for Quantifying GHGs Emissions Reduction}

The GHG emission reduction potential of this study was estimated based on the ACM006 method, namely "Consolidated methodology for electricity and heat generation from biomass" (UNFCCC, 2015). As shown in Fig. 1, to determine both baseline and project emissions, the following sources of GHGs emissions are included:

*Remark: It's assumed that $\mathrm{CO}_{2}$ emissions of surplus biomass residues do not lead to changes of carbon pools in the Land Use, Land-Use Change and Forestry (LULUCF) activities.

\section{Emission Reduction}

Emissions reductions can be calculated by Equations 1-4, as follows:

$$
E R=B E-P E
$$

Where:

$E R=$ Emissions reductions $\left(\mathrm{tCO}_{2} \mathrm{e}\right)$

$B E=$ Baseline emissions $\left(\mathrm{tCO}_{2} \mathrm{e}\right)$

$P E=$ Project emissions $\left(\mathrm{tCO}_{2} \mathrm{e}\right)$

\section{Baseline Emissions}

Baseline emissions can be estimated based on the baseline scenario (without the project). The following emission sources need to be considered:

- Emissions from fossil fuels fired power plants connected to the electricity system

- Emissions from fossil fuels based heat generation that is displaced through the project

- Emissions due to disposal of biomass residues

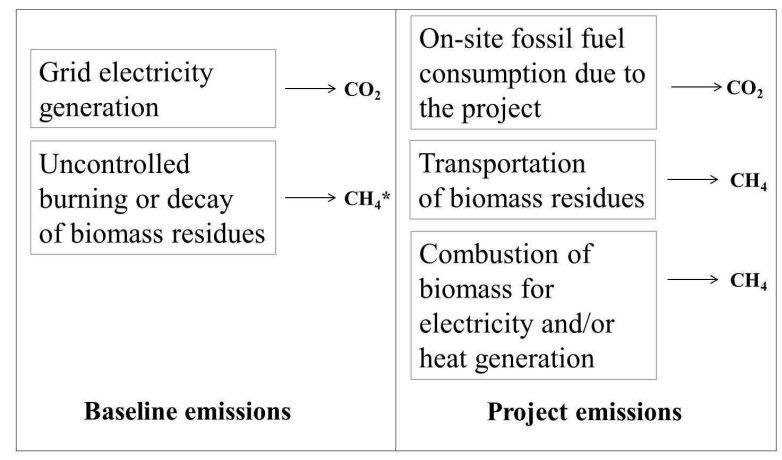

Fig. 1. GHGs sources and project boundaries

Based on the above assumptions, baseline GHGs emissions can be estimated as follows (Equation 2):

$B E=E L_{B L, G R} * E F_{E G, G R}+B E_{B R}$

Where:

$B E=$ Baseline emissions $\left(\mathrm{tCO}_{2}\right)$

$E L_{B L, G R}=$ Baseline electricity generation in the grid or emission reduction due to the displacement of electricity (MWh)

$E F \quad=$ Grid emission factor $\left(\mathrm{tCO}_{2} / \mathrm{MWh}\right)$

$B E_{B R} \quad=$ Baseline emissions due to disposal of biomass residues $\left(\mathrm{tCO}_{2} \mathrm{e}\right)$

The most likely baseline scenario of the bioelectricity generation project is that the biomass residues are dumped, left to decay or burnt in an uncontrolled manner without utilizing them for energy purposes. Baseline emissions can be estimated by multiplying the quantity of biomass residues with the Net Calorific Value (NCV) and an appropriate Emission Factor (EF), as depicted in Equation 3:

$$
B E_{B R}=G W P_{C H 4} * B R * N C V * E F_{B R}
$$

Where:

$B E_{B R} \quad=$ Baseline emissions due to uncontrolled burning of biomass residues $\left(\mathrm{tCO}_{2}\right)$

$G W P_{C H 4}=$ Global Warming Potential of methane valid for the commitment period $\left(\mathrm{tCO}_{2} / \mathrm{tCH}_{4}\right)$

$B R=$ Quantity of biomass residues (tonnes)

$N C V_{B R}=$ Net calorific value of biomass residue (GJ/tonne)

$E F_{B R}=\mathrm{CH}_{4}$ emission factor for uncontrolled burning of the biomass residues $\left(\mathrm{tCH}_{4} / \mathrm{TJ}\right)$

\section{Project Emissions}

The following sources are considered to determine GHGs emissions from project activity (Equation 4):

$P E=P E_{F F}+P E_{G R}+P E_{T R}+P E_{B R}$ 


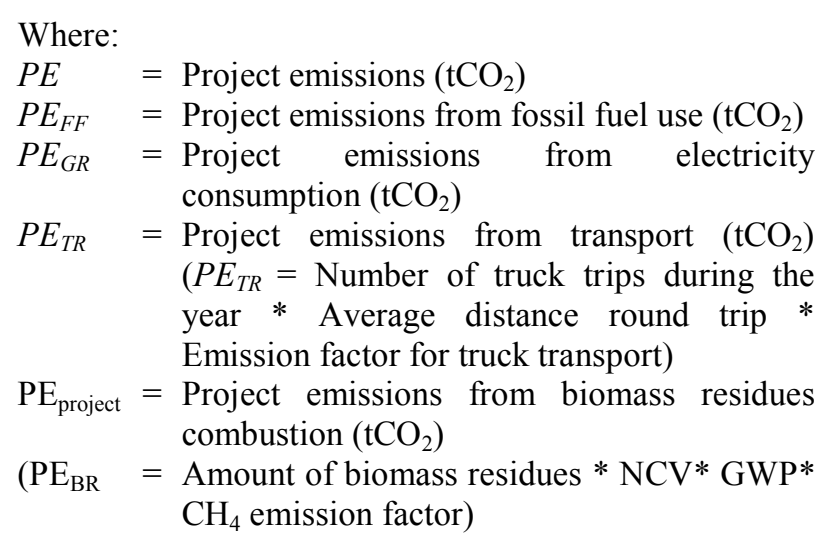

\section{Results and Discussion}

\section{Bio-Electricity Project Description}

The bio-electricity project of the company $\mathrm{A}$ is a thermal-stream cycle power plant, which consists of two high-pressure boilers (Vibrating grate stoker, 120 tph boiler operating at 70 bar and $510^{\circ} \mathrm{C}$ ), turbine generator, cooling tower and electrical substation, as depicted in Fig. 2. In this context, the technology involves the direct combustion of biomass residues in a boiler to generate stream that expands through a turbine. Approximately 4,000 tonnes/day of excess bagasse from the sugar mill and about 100,000 tonnes/year of local agricultural residues (i.e., rice husk) are fed to the project.

\section{Baseline GHGs Emission}

Baseline emission, in this study, is estimated based mainly on the total grid-connected electricity generation (without the bio-electricity project). As shown in Table 4, the net GHGs emissions in the baseline scenario is approximately 103, $288.79 \mathrm{tCO}_{2} \mathrm{e}$ per year. According to an operation of $100 \%$ capacity during peak hours and about $70-80 \%$ capacity during off-peak hours, 330 operation days, the total net electricity is approximately 195,129 MWh per year. GHGs emissions reduction of the displacement of grid electricity generated from fossil fuel need to be considered with baseline scenario. In this context, surplus power of 29,365 MWh is available for exporting to the local grid every year. Therefore, the additional electricity from baseline is about 165,764 MWh per year.

\section{Project Emission}

Since, there is neither electricity input from local grid nor on-site combustion of fossil fuels at the project because on-site electricity consumption is generated from the biomass power plant. Therefore, there are no GHGs emissions from on-site electricity consumption and fossil fuel utilization attributable to the project activity. The total GHGs emission caused by a project activity is about $847.70 \mathrm{tCO}_{2} \mathrm{e}$ per year, as shown in Table 5.

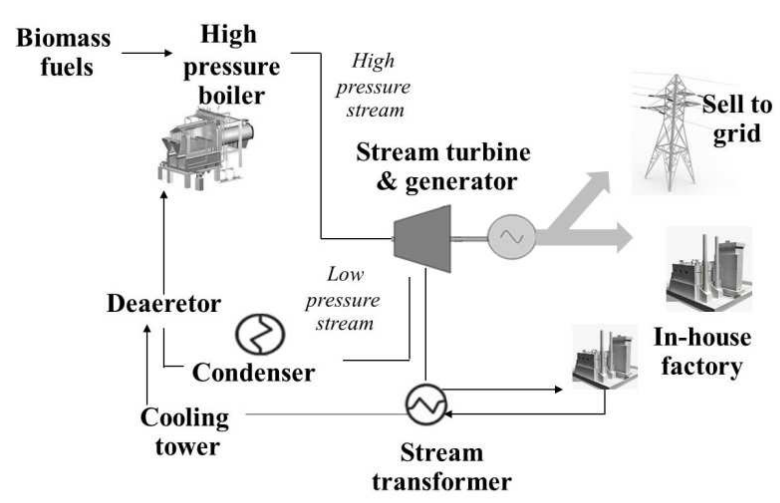

Fig. 2. Process flow diagram: Stream and electricity supplied by high pressure boilers

Total baseline emissions: $103,288.79 \mathrm{tCO}_{2} \mathrm{e}$

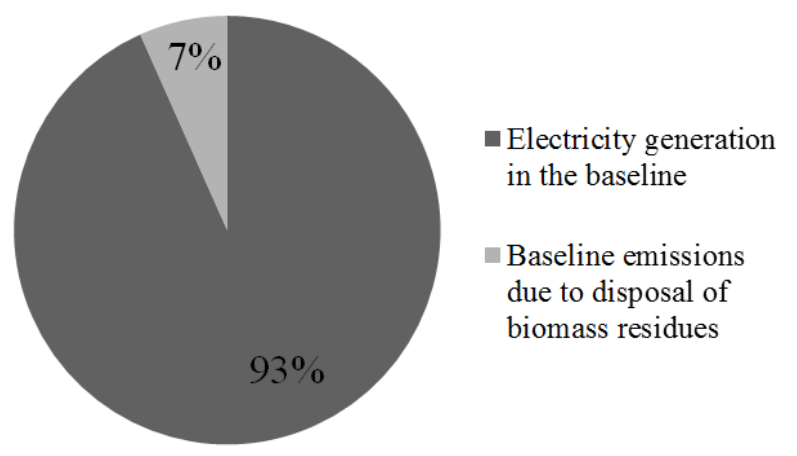

Fig. 3. Total baseline emissions from the bio-electricity project

Total project emisisons: $847.70 \mathrm{tCO}_{2} \mathrm{e}$

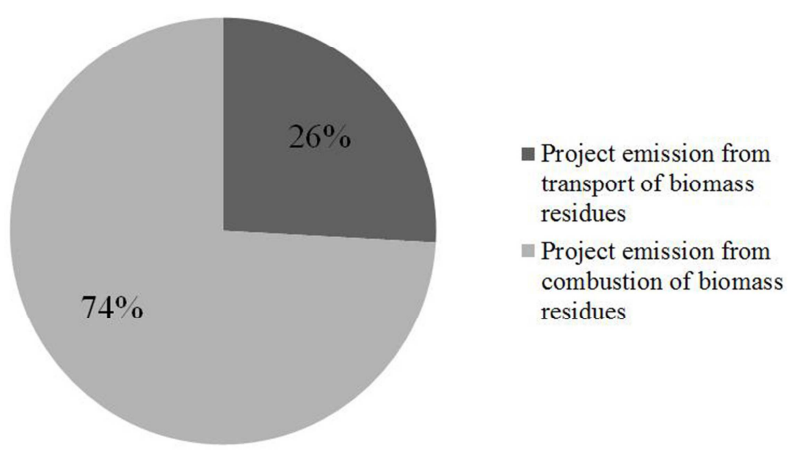

Fig. 4. Total baseline emissions from the bio-electricity project

\section{Emissions Reduction}

Theoretically, the amount of GHGs emission reduction is the difference between the baseline emissions and total emissions from the bio-electricity project. According to Equation 1, the estimation of total annual GHGs reduction is approximately $102,441.09 \mathrm{tCO}_{2} \mathrm{e}$. Figure 3 evidently 
shows that more than $90 \%$ of total baseline emissions came from the annual electricity generated by biomass residues. Compared to project emissions, the combustion of biomass residues accounted for about $74 \%$ of total emissions (Fig. 4). Significantly, the findings indicate that the volume of GHGs emissions from baseline scenario is about 100 times higher than the bio-electricity project emission. These results are comparable to GHGs emission reductions of other bio-energy projects in Thailand as shown in Table 6 (TGO, 2012).

Table 4. Total GHGs emissions in the baseline scenario

\begin{tabular}{lll}
\hline Emissions & & References \\
\hline $\mathrm{EL}_{\mathrm{BL}}, \mathrm{GR}(\mathrm{MWh})$ & 165,764 & $\mathrm{SETW}(2010)$ \\
$\mathrm{EFEG}, \mathrm{GR}$ & 0.5813 & $\mathrm{TGO}(2014)$ \\
$\left(\mathrm{tCO}_{2} / \mathrm{MWh}\right)$ & & \\
$\mathrm{ELBL} * \mathrm{EFEG}\left(\mathrm{tCO}_{2} \mathrm{e}\right)=96,385$ & 4,000 tonnes/day with 330 operation period & Interview results \\
Excess bagasse & 100,000 tonnes/year & Interview results \\
Local rice husk & 0.0074 & \\
$\mathrm{NCV}_{\mathrm{BR}}$ bagasse $(\mathrm{TJ} /$ tonne $)$ & 0.0123 & \\
$\mathrm{NCV}$ & & \\
rice husk $(\mathrm{TJ} /$ tonne $)$ & 0.03 & IPCC $(2000)$ \\
$\mathrm{EF}_{\mathrm{BR}}$ & 21 & IPCC $(2007)$ \\
$\mathrm{GWP}_{\mathrm{CH} 4}$ & & \\
$\mathrm{BE}_{\mathrm{BR}}$ bagasse $=6,128.89 \mathrm{tCO}_{2} \mathrm{e}$ & & \\
$\mathrm{BE}_{\mathrm{BR} \text { rice husk }=774.9 \mathrm{tCO}_{2} \mathrm{e}}$ & \\
Total baseline emission $=103,288.79 \mathrm{tCO}_{2} \mathrm{e}$ & & \\
\hline
\end{tabular}

Table 5. Total GHGs emissions from project activity

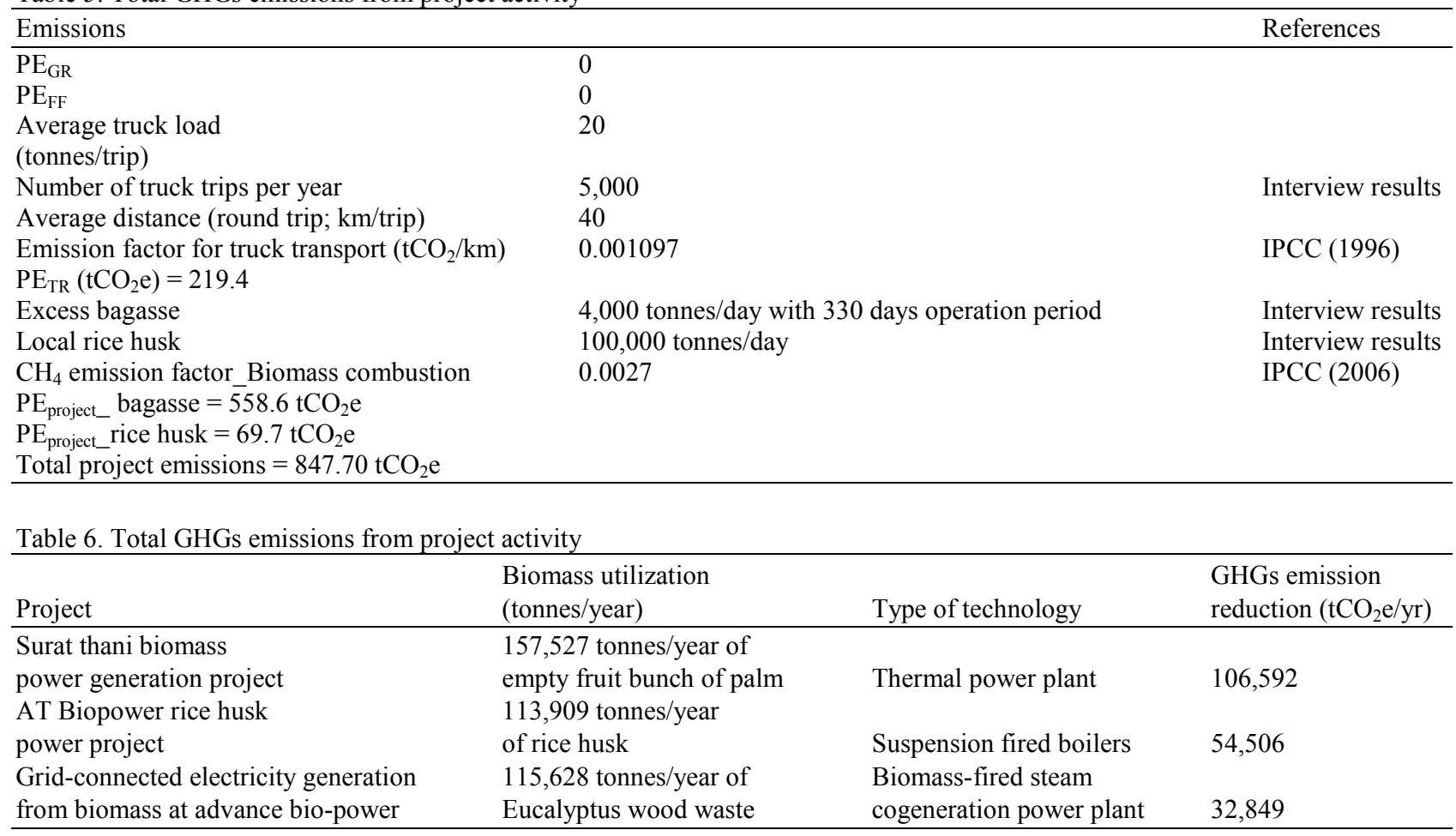

Additionally, if all the bagasse residues in Thailand $(17,630,521$ tonnes in 2009) were to be converted to bioenergy, using the same method of calculation, the estimated total amount of GHGs reduction would be about $1,272,472 \mathrm{tCO}_{2} \mathrm{e}$. Internationally, the study done by EAEW (2009) reported that the total amount of GHGs emissions of bio-energy feedstock was reduced by up to $90 \%$ compared to coal and gas combustion, according to the results of Life Cycle Assessment (LCA).

From the above results, it can be observed that there is a large potential available for renewable energy generation from agricultural residues. However, there are several factors which need to be taken into consideration in implementing bio-energy projects in Thailand. Below are some examples of such factors: 


\section{Lack of Skilled Human Resources}

The implementation of bio-electricity project relies on both experience and understanding on appropriate GHGs emission reduction strategies. It was observed during the site visit that there was a lack of scientific knowledge among the project staff, especially on the generic GHG emission intensity of feedstock based on their agricultural crops.

\section{Lack of Cohesion in Calculation Methods}

Bowyer et al. (2012) speculated that there was a lack of cohesion in international calculation methods for GHGs quantification, clear comparative metric and also agreed basis for estimating emission reductions from bio-energy project.

\section{Lack of Systematic Data Collection}

Gathering existing data is important. However, in fact, there is a lack of systematic data collection for estimating GHGs emissions from the bio-energy project. This study found that it was very difficult to gain access to documents and information on the hauling distance for biomass transportation to the processing plant and number of truck trips during the year and so on.

\section{Uncertainty in the Biomass Supply and Potential Cost}

Uncertainty is one of an important issue in the design and management of bioenergy supply (Nazanin and Taraneh, 2015). Availability and cost of biomass for fuel are subject to variations due to economic fluctuation, market instability, climate and biomass processing operations, etc (Kenney et al., 2013; Shabani et al., 2013). In Thailand, although the country has abundant biomass resources, GEF (2001) reported that there currently exist uncertainties and risks of secure fuel supply at asset price contract for 20 years. Rice mill and rubber wood industries have the least uncertainties of fuel supply for bio-energy project in Thailand due to the stable market growth. However, agricultural waste residues are mainly unused for power generation probably because of uncertainty in logistics and the cost of the resource for any larger scale energy production (Siemers, 2010).

The following policy recommendations and potential actions can be drawn from above discussion:

National government should support capacity building for all local municipality, community, private sector and related stakeholders to accelerate development of bio-energy project. Industrial operators have to recognize all benefits of the installation of the bioelectricity instead of the conventional energy technology. It is also important to build mechanisms and promote collaboration between private and public sectors to facilitate investment in GHGs emissions reduction technologies (i.e., high pressure and high temperature boiler cogeneration systems). Biomass-Trade-Center (BTC), a mediator between local biomass potential and fuels demand generated by bio-electricity projects should be established in the country and/or the region.

Expert should provide both scientific and technical advice on bio-energy and climate change mitigation related issues to all stakeholders. Both methods for calculating GHG emissions in the bio-energy project and carbon trading information should be easily accessible for all project developers. Related stakeholders should provide technical support and R\&D on the concept of Measuring, Reporting and Verification (MRV), carbon capture and sequestration technologies (Liang et al., 2013), LCA-type studies and GHGs mitigation strategies at both local and national scales.

National government should provide more financial incentives for the bio-electricity development in the country (i.e., agricultural grant for installing biomass boilers and/or green bonuses in case of renewable electricity production and consumption). Government also should help alleviate the investment cost the biomass-fueled power plant installation in the country. This, in turn, the revision of Thailand's FiT program should incorporate lessons from successful experiences in other countries (Tongsopit and Greacen, 2013). Meanwhile, financial analysis should be systematically conducted by considering the production costs per unit of bio-electricity generation and GHGs emissions reduction. GHG estimation methods in the bio-energy sector should be clearly documented and also standardized.

In terms of the availability of additional biomass for energy purposes, collection and preparation of databases are also urgently required. As such, government needs to provide forecasts of future needs, comprehensive evaluations of available renewable energy resources in the country and the possible options to utilizing them. Actual amounts of agricultural residual and unexploited biomass should be more accuracy accounted.

\section{Conclusion}

To improve energy security and alleviate the problem of global climate change, bagasse based cogeneration in sugar mills and biomass power generation could potentially reduce the amount of GHGs emissions to the atmosphere. Approximately $102,441.09 \mathrm{tCO}_{2} \mathrm{e}$ per year of total GHGs reduction was estimated based on the amount of 1,320,000 and 100,000 tonnes per year of excess bagasse and rice husk residues, respectively. In baseline scenario, over ninety percent of total GHGs came directly from the generation of electricity based biomass residues. Compared to the project emission, the combustion of biomass residues accounted as the main source of emission. 


\section{Acknowledgement}

The authors thank the Higher Education Commission (OHEC) and the S\&T Postgraduate Education and Research Development Office (PERDO) for financial support of the research program entitled "The Toxic substance management in the mining industry". We also would like to express our sincere thanks to the Environmental Research Institute (ERIC) and the Center of Excellence on Hazardous Substance Management (HSM) Chulalongkorn University for their invaluable supports in terms of facilities and scientific equipment.

\section{Author's Contributions}

Kittipongvises Suthirat: Designed and wrote the manuscript.

Polprasert Chongrak: Conceived and revised the manuscript.

\section{Conflict of Interest}

The authors declare no conflict of interest.

\section{References}

Bowyer, C., Baldock, D., Kretschmer, B. and Polakova, J., 2012. The GHG emissions intensity of bioenergy: Does bioenergy have a role to play in reducing GHG emissions of Europe's economy? Institute for European Environmental Policy (IEEP): London.

EPPO, 2010. Promotion on electricity generation from renewable energy. Energy Planning and Policy Office.

EAEW, 2009. Minimizing from bioenergy generation. Environment Agency for England and Wales.

EPC, 2009. Directive 2009/28/EC of 23 April 2009 on the promotion of the use of energy from renewable sources and amending and subsequently repealing Directives 2001/77/EC and 2003/30/EC. European Parliament and the Council.

GEF, 2001. Project of the Government of Thailand. Global Environment Facility.

IEA, 2009. Cities, towns and renewable energy: Yes in my front yard. International Energy Agency. Paris.

IPCC, 2007. Summary for Policymakers. In: Climate Change 2007: The Physical Science Basis. Contribution of Working Group I to the Fourth Assessment Report of the Intergovernmental Panel on Climate Change, Solomon, S., D. Qin, M. Manning, Z. Chen and M. Marquis et al., (Eds.), Cambridge University Press, USA.

IPCC, 2006. 2006 IPCC guidelines for national greenhouse gas inventories, prepared by the national greenhouse gas inventories programme, IGES, Japan.

IPCC, 2000. Good practice guidance and uncertainty management in national greenhouse gas inventories. Intergovernmental Panel on Climate Change.
IPCC, 1996. Guidelines for national greenhouse gas inventories. IPCC.

Kenney, K.L., W.A. Smith and G.L. Gresham, 2013. Understanding biomass feedstock variability. Biofuels, 4: 111-127.

Liang, X., Z. Wang, Z. Zhou, Z. Huang, J. Zhou and K. Cen, 2013. Up-to-date life cycle assessment and comparison study of clean coal power generation technologies in China. J. Cleaner Product., 39: 24-31. DOI: 10.1016/j.jclepro.2012.08.003

NSTIPO and JGSEE, 2014. National science technology and innovation policy office and joint graduate school of energy and environment. Thailand Bioenergy Technology Status Report 2013.

Nazanin, S. and S. Taraneh, 2015. Evaluating the impact of uncertainty and variability on the value chain optimization of a forest biomass power plant using Monte Carlo Simulation. Int. J. Green Energy, 13: 631-641. DOI: 10.1080/15435075.2014.993764

ONESDB, 2011. The eleventh national economic and social development plan (2012-2016). Office of the National Economic and Social Development Board, Thailand.

ONEP, 2010.Thailand's second national communication under the united nations framework convention on climate change. Office of Natural Resources and Environmental Policy and Planning, Bangkok, Thailand.

Pita, P., W. Tia, P. Suksuntornsiri, B. Limpitipanich and B. Limmeechockchai, 2015. Assessment of feed-in tariff policy in Thailand: Impacts on national electricity prices. Energy Procedia, 79: 584-589. DOI: 10.1016/j.egypro.2015.11.537

Serdar, Ö., S. Ali and Ö. Ülger, 2013. The real crisis waiting for the world: Oil problem and energy security. Int. J. Energy Econom. Policy, 3: 74-79.

Shabani, N., S. Akhtari and T. Sowlati, 2013. Value chain optimization of forest biomass for bioenergy production: A review. Renewable Sustainable Energy Rev., 23: 299-311.

DOI: $10.1016 /$ j.rser.2013.03.005

Siemers, W., 2010. Greenhouse gas balance for electricity production from biomass resources in Thailand. J. Sustainable Energy Environ., 1: 65-70.

SETW, 2010. Good practice: Dan chang bio-energy cogeneration project (DCBC), Thailand. Sustainable Energy Technology at Work.

Sutabutr, T., 2012. Alternative energy development plan: AEDP 2012-2021. Int. J. Renewable Energy, 7: 1-10.

TGO, 2014. Carbon Footprint for Organization: Emission factor. Thailand Greenhouse Gas Management Organization

TGO, 2012. CDM projects registered by the CDM executive board. TGO. 
Theerarattananoon, K., 2015. RE/PV plans PV and utilities workshop. Department of Alternative Energy Development and Efficiency, Ministry of Energy, Thailand.

Tongsopit, S. and C. Greacen, 2013. An assessment of Thailand's feed-in tariff program. Renewable Energy, 60: 439-445.
UNFCCC, 2015. ACM0006: Consolidated methodology for electricity and heat generation from biomass. United Nations Framework Convention on Climate Change. 